\title{
Impact of Service Quality on Customer Satisfaction in Hotel Industry
}

\author{
Dr. P. Srinivas Rao and Dr.Padma Charan Sahu \\ Professor, Administrative Management College, Bangalore \\ (Integrated Development), AMC - CITY Institutions, Bangalore
}

\begin{abstract}
Customer satisfaction means that how the customer perceives service delivery. That customer satisfaction is a function of service performance relative to the customer expectation. For this reason, it is important to understand how customer expectation is formed in order to identify the factors of service satisfaction in the hotel industry. As different customers have different expectations, based on their knowledge of a product or service Reisig \& Chandek (2001). This can be implied that a customer may estimate what the service performance will be or may think what the performance ought to be. If the service performance meets or exceeds customers' expectation, the customers will be satisfied. Previous research explored customer satisfaction regarding the service quality of all areas in the hotel so that the hotel can assess the customer perception. This study identified five factors of service quality by focusing on the front office staff only, and explored the customers' expectations and perception levels of these services. The results of this quantitative assessment of service quality might provide some insights into how customers rate the service quality and assessed customers' satisfactions.
\end{abstract}

Key words: Customer satisfaction, customer expectation, customer perception, service quality and service satisfaction.

\section{Introduction}

The trend of world markets has changed noticeably from agricultural to service markets (Asian Development Outlook, 2007). All of the service businesses are trying their best to improve their service quality in order to make customers satisfied with their services, especially the hotel industry. Hotel operators now focus more on the quality standards in order to meet the basic needs and expectations of the customers. Once customers' requirements are clearly identified and understood, hotel operators are more likely to anticipate and fulfil their customers' needs and wants (Juwaheer \& Ross, 2003). The more satisfied the customers are, the more likely they are to return or prolong their hotel stay (Choi \& Chu, 2001).

At present, hotel visitors in Bhubaneswar, Odisha seem to have high standards and demands for excellent service. The hotels have increased their competition and now instead of having only a nice room to draw customers in, they offer high quality staff" as an amenity as well. Guest satisfaction is the highest priority for owners and managers competing with hundreds of others, and personal service is at the top of the travellers' list of the most important things when considering a hotel to stay in (Wipoosattaya, 2001). In the hotel industry, hotel staffs are ranging from top management staff to front line staff (i.e. housekeepers, receptionists, front cashiers). Front office staffs are considered a supporting factor in determining customer satisfaction when deciding to return, to recommend the hotel, or in demonstrating loyalty to a particular hotel (Kandampully \& Suhartanto, 2000).

In addition, Watt (2007) stated that the front office is an important function because customers deal with front office staff as the center of the hotel. They provide assistance to guests, fulfil their needs, and meet their wants. As mentioned above, service quality was determined as the subjective comparison that customers make between their expectations about a service and the perception of the way the service has been run. Parasuraman et al. (1985) defined service quality as a function of the differences between expectation and performance along ten major dimensions. In later research, Parasuraman et al. (1988) revised and defined the service quality in terms of five dimensions: tangibility, reliability, responsiveness, assurance, and empathy. For example, Min and Min (1997) presented the idea that front office services have the attributes that are considered most important, particularly in forming the following impressions of service quality; tangibility (how well the hotel staff are dressed); reliability (ability to resolve problems encountered by guests); responsiveness (convenience of making the reservation, promptness of check-in/check- out process, hotel/tour guide information); assurance (security and safety of guests); \& empathy (caring and individualized attention). 


\section{Objectives of the Study}

- To assess customers' expectation and perception level towards service quality of the front office staff in five dimensions: tangibility, reliability, responsiveness, assurance, and empathy.

- To analyze the discrepancy gap between customers' expectation and perception towards service quality of the front office staff.

\section{Previous literature}

Based on Parasuraman et al. (1988) conceptualization of service quality, the original SERVQUAL instrument included 22 items. The data on the 22 attributes were grouped into five dimensions: tangibles, reliability, responsiveness, assurance, and empathy. This instrument has been made to measure service quality in a variety of services such as hospitals (Babakus \& Glynn 1992), hotels (Saleh \& Rylan 1991), travel and tourism (Fick \& Ritchie 1991), a telephone company, two insurance companies and two banks (Parasuraman et al. 1991). In this study, the researcher uses SERVQUAL approach as an instrument to explore customers' expectations and perceptions levels of service quality towards the front office staff at the hotel.

\section{Customers' Satisfaction}

The satisfaction is an attitude or evaluation that is formed by the customer comparing their prepurchase expectations of what they would receive from the product to their subjective perceptions of the performance they actually did receive (Oliver, 1980). As Kotler (2000, p.36) defined that satisfaction is a person's feelings of pleasure or disappointment resulting from comparing a product's perceived performance (or outcome) in relation to his or her expectation. Additionally, Yi (1990) also stated that customer satisfaction is a collective outcome of perception, evaluation and psychological reactions to the consumption experience with a product/service.

\section{Customers' Expectation}

Davidow and Uttal (1989) proposed that customers' expectation is formed by many uncontrollable factors which include previous experience with other companies, and their advertising, customers' psychological condition at the time of service delivery, customer background and values and the images of the purchased product. Zeithaml et al. (1990) stated that customer service expectation is built on complex considerations, including their own pre-purchase beliefs and other people's opinions. Similarly, Miller also stated that customers' expectation related to different levels of satisfaction. It may be based on previous product experiences, learning from advertisements and word-of-mouth communication. The diversity of expectation definitions can be concluded that expectation is uncontrollable factors which including past experience, advertising, and customers' perception at the time of purchase, background, attitude and product's image. Furthermore, the influence of customers' expectation is pre-purchase beliefs, word of mouth communications, individual needs, customers' experiences, and other personal attitudes. Different customers have different expectation based on the customers' knowledge of a product or service.

\section{Disconfirmation Theory}

In marketing literature (Churchill and Surprenant, 1982; Oliver, 1980) as well as in recent information system studies (McKinney et al., 2002), the disconfirmation theory emerges as the primary foundation for satisfaction models. According to this theory, satisfaction is determined by the discrepancy between perceived performance and cognitive standards such as expectation and desires (Khalifa and Liu, 2003).

Phenphun (2003) studied International tourist' satisfaction with the quality of service in accommodation in Thailand and the factors related to satisfaction, problems and the requirements of international tourists. The research revealed the satisfaction of international tourists towards quality of service was at a high level. However, the most common problems were lack of employee's knowledge and English skill, therefore, tourists suggested language and convenient facility improvement. In the 2001 study tour of Taiwan, $\mathrm{Yu}$ (2001) indicated that it might be possible to create service quality evaluations that are more accurate instruments for measuring the quality of service in the various service sectors, as Crompton et al.(1991) suggested. For the best indicators of service quality in the tourism sector, the tourist's experience might be the key indicator for evaluating tourism quality because the tourism industry is essential people serving people.

\section{Methodology}

For this study we have taken the help of primary as well as secondary data. The primary source of data for the present study comprises of a set of structured questionnaire administered among the borders chosen randomly. The secondary information is gathered from the official publications, records, text books, magazines, journals, and published materials. A total of 100 respondents were considered for this study Statistical tools like measures of central tendency and dispersion shall be used to analysis the data so collected for the purpose. 


\section{Analysis and findings}

Only 60 customers were returned, the duly filled in, questionnaire. The period of study was from $1^{\text {st }}$ to $31^{\text {st }}$ March, 2013. The profile covers the gender, age, nationality, occupation, purpose of trip and duration of stay the hotel. The findings showed that there were more females customers (57\%) than male (43\%). The largest age group was between 25 and 35 years of age (43\%). The majority (44\%) of the respondents were Delhites and $54 \%$ were employees. The main purpose of their visits included vacation (69\%), business (20\%), honeymoon $(8 \%)$, and seminar/conference $(3 \%)$. $36 \%$ of the respondents had stayed at the hotel on two occasions while only $3 \%$ had stayed there 4 times. $80 \%$ customers opined positively of their choice to repeat visit whereas, $95 \%$ expressed their compliments with the services extended to them during their stay.

Service quality is composed of tangibility, reliability, responsiveness, assurance, and empathy. The 60 respondents were asked to rate each statement concerning their expectation and perception of service quality of front office staff of May Fair Hotel. The analytical findings of the service quality of each dimension were as follows:

\section{Tangibility}

The tangibility dimension includes physical aspects such as the physical appearance of hotel services including the neatness of front office staff and professionalism of employees (Dabholkar et al., 1996).

Table 1 Customers' satisfaction concerning tangibility

\begin{tabular}{|l|l|l|l|l|l|l|}
\hline \multirow{2}{*}{ Tangibility Dimension } & Customers' Expectation & \multicolumn{3}{l|}{ Customers' Perception } \\
\cline { 2 - 7 } & Mean & S.D & Level & Mean & S.D & Level \\
\hline Staff dress appropriately & 3.85 & 0.68 & High & 4.43 & 0.53 & Highest \\
\hline Cleanness of dress & 3.97 & 0.68 & High & 4.53 & 0.56 & Highest \\
\hline Service with a smile & 3.92 & 0.82 & High & 4.45 & Highest & 0.56 \\
\hline $\begin{array}{l}\text { Attractive appearance (Smartness, } \\
\text { elegant) }\end{array}$ & 3.97 & 0.78 & High & 4.40 & 0.64 & Highest \\
\hline Overall Mean score & 3.92 & 0.52 & High & 4.45 & 0.41 & Highest \\
\hline
\end{tabular}

Sources: Compiled Primary data

Table 1 show that overall satisfaction of expectation towards tangibility is at a high level (3.92). Cleanliness of uniform and appearance of staff both received high ranking at 3.97. When front office staffs are well dressed and wear smart uniforms, their appearance impresses customers who feel more confident with hotel services.

Customer perception of tangibility dimension was also ranked at the highest level (4.45). The findings are supported by Wong et al. (1999), who studied SERVQUAL dimensions in the hospitality industry in Malaysia. They found that service quality was related to the tangible behaviour and appearance of employees. The best predictor of overall service quality was the tangibility dimension.

\section{Reliability}

The reliability dimension refers to the ability of the front office hotel staff to provide services dependably and accurately (Dabholkar et al., 1996). Reliable service performance has to meet customers' expectation. Service must be accomplished on time, every time, in the same manner and without errors.

Table 2 Customer satisfaction concerning reliability

\begin{tabular}{|l|l|l|l|l|l|l|}
\hline \multirow{2}{*}{ Reliability Dimension } & Customers' Expectation & \multicolumn{3}{l|}{ Customers' Perception } \\
\cline { 2 - 7 } & Mean & S.D & Level & Mean & S.D & Level \\
\hline Provides service as promised & 3.95 & 0.685 & High & 4.38 & 0.533 & Highest \\
\hline Provides accurate information & 3.88 & 0.688 & High & 4.33 & 0.566 & Highest \\
\hline Perform service correctly & 3.88 & 0.829 & High & 4.25 & 0.565 & Highest \\
\hline $\begin{array}{l}\text { Tell exactly when service be } \\
\text { provided }\end{array}$ & 4.02 & 0.780 & High & 4.25 & 0.643 & Highest \\
\hline Overall Mean score & 3.93 & 0.554 & High & 4.30 & 0.451 & Highest \\
\hline
\end{tabular}

Sources: Compiled Primary data

Table 2 depicts that overall satisfaction of expectation concerning reliability dimension is high (3.93). This rating is supported by comments by a frequent guest at the hotel who wrote "The room is ready on time upon check in and get the late check out until 2 p.m. every time of customers' stay at this hotel." Overall satisfaction of perception towards reliability dimension is also at the highest level (4.30), with "The staffs provide service as promised" receiving the highest score (4.38). This may be because the front office staff provide service correctly the first time and keep their promises to customers. Consequently, customers feel satisfied with the reliability of service.

\section{Responsiveness}

The responsiveness dimension involves willingness to help customers and provide prompt services (Zeithaml et al., 1988). It is essential that front office hotel staff is willing and able to help customers provide prompt service and meet customers' expectation. 
Table 3 customer satisfaction concerning responsiveness

\begin{tabular}{|c|c|c|c|c|c|c|}
\hline Responsive Dimension & \multicolumn{3}{|c|}{ Customers' Expectation } & \multicolumn{3}{|c|}{ Customers' Perception } \\
\hline The staff give prompt service & 3.83 & 0.827 & High & 4.23 & 0.566 & Highest \\
\hline Overall Mean score & 3.98 & 0.640 & High & 4.33 & 0.545 & Highest \\
\hline
\end{tabular}

\section{Sources: Compiled Primary data}

Table 3 shows that overall expectation towards responsiveness dimension was at the high level (3.98). "The staffs respond to your request quickly" received the highest ranking of expectation at 4.12. It is highly possible that customers are satisfied when they receive a quick response from the hotel staff. This is supported by a first time customer at the hotel who commented that, "The front office staffs are willing to help me when the customer is looking for the hotel direction. It makes him feel that the staffs are full of service mind in heart". This shows that this customer received good help when needed. The ability to respond to customers' requests reflected to customer satisfaction.

Table 3 also shows that overall satisfaction of perception towards responsiveness dimension was at a high level (3.98). The two highest ranking points concerned quick response and willingness to help. These findings are consistent with Parasuraman et al. (1998), who measured consumer perceptions of service quality. They found that responsiveness was the most important factor in determining customer satisfaction with service.

\section{Assurance}

The assurance' dimension refers to the knowledge and courtesy of employees and their ability to inspire trust and confidence including competence, courtesy, credibility and security (Parasuraman et al., 1991).

Table 4 Customer satisfactions concerning assurance

\begin{tabular}{|l|l|l|l|l|l|l|}
\hline \multirow{2}{*}{ Assurance Dimension } & \multicolumn{4}{l|}{ Customers' Expectation } & \multicolumn{3}{l|}{ Customers' Perception } \\
\cline { 2 - 7 } & Mean & S.D & Level & Mean & S.D & Level \\
\hline $\begin{array}{l}\text { The staff have product } \\
\text { Knowledge of the hotel }\end{array}$ & 4.10 & 0.706 & High & 4.62 & 0.643 & Highest \\
\hline $\begin{array}{l}\text { The staff have the skills } \\
\text { required to perform service }\end{array}$ & 3.95 & 0.746 & High & 4.37 & 0.610 & Highest \\
\hline $\begin{array}{l}\text { The staffs speak with you by } \\
\text { appropriate forms. }\end{array}$ & 3.95 & 0.832 & High & 4.35 & 0.606 & Highest \\
\hline The staff are trustworthy & 4.17 & 0.806 & High & 4.30 & 0.671 & Highest \\
\hline $\begin{array}{l}\text { The staff make you feel safe } \\
\text { when staying at the hotel }\end{array}$ & 4.10 & 0.752 & High & 4.22 & 0.640 & Highest \\
\hline Overall Mean score & 4.05 & 0.561 & High & 4.37 & 0.440 & Highest \\
\hline
\end{tabular}

Sources : Compiled Primary data

Table 4 shows that overall expectation towards assurance dimension was at a high level (4.05), with trustworthiness ranking most important (4.17). Most customers expect front office staff to make them feel safe when staying at the hotel. In addition, Accounhtant should be credible and responsible when handling expenses or money from guests.

Perception of assurance dimension ranked at the highest level (4.37), with product knowledge being the most important factor (4.62). Front office staff must have broad and deep knowledge, skills, capacity and experience. They must also be well versed in using advanced technology to improve their performance such as when making room reservations by computer.

\section{Empathy}

The empathy dimension represents the provision of caring and individualized attention to customers including access or approachability and ease of contact, effective communication, and understanding the customers (Parasuraman et al., 1991).

Table 5 Customer satisfaction concerning empathy

\begin{tabular}{|l|l|l|l|l|l|l|}
\hline \multirow{2}{*}{ Empathy dimension } & \multicolumn{3}{l|}{ Customers' Expectation } & \multicolumn{2}{l|}{ Customers' Perception } \\
\cline { 2 - 7 } & Mean & S.D & Level & Mean & S.D & Level \\
\hline $\begin{array}{l}\text { The staff are able to communicate } \\
\text { with you in English }\end{array}$ & 4.00 & 0.736 & High & 4.28 & 0.524 & Highest \\
\hline $\begin{array}{l}\text { The staffs are able to } \\
\text { communicate effectively. }\end{array}$ & 4.17 & 0.693 & High & 4.22 & 0.739 & Highest \\
\hline $\begin{array}{l}\text { The staff show personal attention } \\
\text { to you }\end{array}$ & 4.05 & 0.790 & High & 4.37 & 0.663 & Highest \\
\hline $\begin{array}{l}\text { The staff know your specific } \\
\text { needs }\end{array}$ & 3.88 & 0.825 & High & 4.28 & 0.783 & Highest \\
\hline Overall Mean score & 4.02 & 0.563 & High & 4.28 & 0.530 & Highest \\
\hline
\end{tabular}

Sources : Compiled Primary data 
Table 5 showed that overall expectation concerning assurance dimension was at a high level (4.02). Effective communication was considered the most important (4.17) expectation. The front office staffs represent the hotel and communication is vitally important. The success of hotel work is based on effective communication (Paige, 1977). The front office deals with reservations, serves as the information centre and as the cashier. They must notify the housekeeping and kitchen divisions of guest information, and also receive feedback. Effective communication among divisions in the hotel is one of the main factors that contribute to customer satisfaction.

Table 4.11 also shows that overall perception of the assurance dimension was at the highest level (4.28). Perception of the personal attention of the staff was ranked highest at 4.37. The results indicated that the front office staffs were enthusiastic to help hotel guests. One first time customer commented, "The bell boy brought baggage immediately to the shuttle bus upon check out customers". According to Crompton et al. (1991), staff should make customers feel like they belong. This statement is consistent with the definition of empathy.

\section{Overall customer satisfaction towards service quality}

Table 6 Overall mean score of customer satisfaction towards service quality

\begin{tabular}{|l|l|l|l|l|l|l|}
\hline \multirow{2}{*}{ Five Dimension } & \multicolumn{4}{l|}{ Customers' Expectation } & \multicolumn{3}{l|}{ Customers' Perception } \\
\cline { 2 - 8 } & Mean & S.D & Level & Mean & S.D & Level \\
\hline Tangibility & 3.92 & 0.52 & High & 4.45 & 0.415 & Highest \\
\hline Reliability & 3.93 & 0.55 & High & 4.30 & 0.451 & Highest \\
\hline Responsiveness & 3.98 & 0.60 & High & 4.33 & 0.545 & Highest \\
\hline Assurance & 4.05 & 0.56 & High & 4.37 & 0.440 & Highest \\
\hline Empathy & 4.02 & 0.56 & High & 4.28 & 0.530 & Highest \\
\hline Overall Mean score & 3.98 & 0.38 & High & 4.35 & 0.355 & Highest \\
\hline
\end{tabular}

Sources: Compiled Primary data

Table 6 shows that overall satisfaction of expectation towards the five dimensions was at a high level (3.98). The result of customers' expectation showed that assurance dimension was at the high level (4.05), followed by empathy (4.02), responsiveness (3.98), reliability (3.93), and tangibility (3.92). Most customers expected the front office staff (specially Accountant) to be trustworthy because they are responsible for the hotel expenses or collecting money from hotel guests.

Overall satisfaction of perception towards the five dimensions was at the highest level (4.35). Most customers perceived tangibility as the most important dimension at (4.45), followed by assurance (4.37), responsiveness (4.33), reliability (4.30), and empathy (4.28). In this study, tangibility dimension was the most vital factor. Most customers identified the importance of the appearance and cleanliness of the front office staff. The SERVQUAL gap is calculated between the mean score of expectation and perception. The findings of the study showed the difference between expectation and perception as shown in the table below.

Table 7 SERVQUAL gap of customers' expectation and perception towards the service quality of front office staff at the hotel

\begin{tabular}{|l|l|l|l|}
\hline Attributes & $\begin{array}{l}\text { Customers' } \\
\text { Expectations }\end{array}$ & $\begin{array}{l}\text { Customers' } \\
\text { Perception }\end{array}$ & $\begin{array}{l}\text { SERVQUAL } \\
\text { Gap }\end{array}$ \\
\hline Pair 1) Tangibility & 3.92 & 4.45 & 0.53 \\
\hline Pair 2) Reliability & 3.93 & 4.30 & 0.37 \\
\hline Pair 3) Responsiveness & 3.98 & 4.33 & 0.35 \\
\hline Pair 4) Assurance & 4.05 & 4.37 & 0.32 \\
\hline Pair 5) Empathy & 4.02 & 4.28 & 0.26 \\
\hline Overall mean score & 3.98 & 4.35 & 0.37 \\
\hline
\end{tabular}

\section{Sources: Compiled data}

Table 7 demonstrates the gap between customers' expectation and perception. The study shows that the overall level of perception of all dimensions was higher than level of expectation. This positive gap indicates that customers are satisfied with the services.

Tangibility' was the most important dimension with the highest positive gap (0.53). The study revealed that physical evidence such as uniforms, appearance and behaviour of front office staff yield customer satisfaction. Similarly, Ramchurrun (2008) suggested that customers attached importance to the dimension of tangibility because services are intangible. Hence, customers place great importance on the appearance neatness of the staff.

\section{Conclusion}

Service businesses have been growing rapidly in recent decades, while customer demand for high quality service is increasing.. To remain competitive, the hotel needs to analyze customers' expectation and perception towards the service quality of its front office staff. In this research, the SERVQUAL instrument, developed by Parasuraman (1985), has been applied in designing the questionnaire by using five dimensions of service quality Data collected from a questionnaire were distributed to 100 guests who stayed at the May Fair Hotel Bhubaneswar between $1^{\text {st }}$ to $31^{\text {st }}$ March, 2013. The questionnaire aimed to determine the level of 
customers' expectation and perception towards the service quality of front office staff. The results revealed that the assurance' dimension raised the highest level of expectation, whereas the tangibility' dimension fulfilled the highest level of perception.

This study focused further on the gap between customers' expectation and their perception of front office service quality. The results showed that the overall mean score of perception was higher than expectation in all dimensions, yielding a positive SERVQUAL gap. In this study, the findings showed that most respondents identified tangibility as the most important factor in determining satisfaction. Moreover, their perception of service exceeded their expectation. The findings of this study were in contrast with previous study of Juwaheer and Ross (2003) who studied service quality in Mauritian hotels. They found that by focusing on assurance and reliability, a hotel could achieve high levels of satisfaction and service quality. From the above it can be concluded that the front office staff are the nerve center of all hotels, and the front office is essential to keep up with what is happening at all areas of the hotels.

In conclusion, the result showed a positive gap between customers' expectation and perception towards service quality of front office staff. Customers' perception level was higher than their expectation. It is obvious that most customers felt satisfied with the service quality of the front office staff at the Hotel May Fair, Bhubaneswar. For betterment these things can be taken inconsideration

- Empathy was shown to be the weakest dimension of satisfaction. Therefore, hotel management should arrange special courses to improve effective communication.

- Tangibility was shown to be the strongest dimension of satisfaction. Therefore, hotel management should maintain the attributes of tangible service quality at the hotel.

- Human Resource management should arrange in-house training program to improve the main work of front office staff and to promote them in their careers.

The limitation of this study is that the findings cannot be accepted as cent percent correct as the scope, time and size of sample is very less. With this small size of sample of a single organization the result cannot be considered genuine. Hence further study is very essential in the matter. First, research could be broadened to include other star hotels of metropolitan cities. It would be valuable to conduct further research concerning customers' attitudes towards the quality of other service businesses such as restaurants, travel agencies and airlines.

References

[1]. Churchill, G.A. \& Suprenant, C. (1992) An Investigation into the Determinant of Customer Satisfaction. Journal of Marketing Research, Vol.19, pp.491-504.

[2]. Dabholkar, P.A., Thorpe, D.I. \& Rentz, J.O. (1996). A measure of service quality for retail stores: scale development and validation. Journal of the Academy of Marketing Science, pp. 3-16.

[3]. Davidow, W. H. \& Uttal, B. (1989). Service Companies: Focus or Falter. Harvard Business Review, July-August: 77-85.

[4]. Kandampully, J. \& Suhartanto, D. (2000). Customer loyalty in the hotel industry: The role of customer satisfaction and image. International Journal of ContemporaryHospitality Management, 12(6), 346-351.Kotler, P. (2003). Marketing Management. (11th ed.) NJ: Prentice Hall, Inc

[5]. McKinney, V., Yoon, K. \& Zahedi, F.M. (2002). The Measurement of Web-Customer Satisfaction: An expectation and Disconfirmation Approach. Information System Research, Vol.13, No.3, September, pp. 296-315.

[6]. Min, H.K., \& Min, H.S. (1997). Benchmarking the quality of hotel services: Managerial perspectives. International Journal of Quality \& Reliability Management, 14(6), 582-597.

[7]. Oliver, R. L. (1980). A Cognitive Model of the Antecedents and Consequences of Satisfaction Decisions. Journal of Marketing Research, Vol. XVII, November.

[8]. Parasuraman. A., Zeithaml, V.A. \& Berry, L.L. (1985 \& 1988). A conceptual model of service quality and its implication. Journal of Marketing, Vol.49, Fall, pp. 41-50.

[9]. Reisig Michael D., Meghan Stroshine Chandek (2001). The effects of expectancy disconfirmation on outcome satisfaction in policecitizen encounters. An International Journal of Police Strategies \& Management 24(1): 88-99

[10]. Watt. Paul. (2007). Customer service work and emotional labour in the hospitality industry. UK: University of London

[11]. Wipoosattaya, W. (2001). Tourist's perceptions of hotel frontline employees' questionable job-related behavior. Bangkok: Thesis (MBA) - Assumption University.

[12]. Yi, Y. (1990). A critical review of consumer satisfaction. Review of Marketing 1990, American Marketing Association, Chicago, IL.

[13]. Yu, Alvin Hung-Chih. (2001). Service quality in Tourism : A case study of the 2001 study tour of Taiwan. Leisure Studies, The Pennsylvania State University: USA.

[14]. Zeithaml V.A., Parasuraman A., \& Berry L.L. (1990). Delivering quality service: Balancing customer perceptions and expectations. The Free Press, New York. NY. 